\title{
Progressive resistance of BTK-I43 osteosarcoma cells to Apo2L/TRAIL-induced apoptosis is mediated by acquisition of DcR2/TRAIL-R4 expression: resensitisation with chemotherapy
}

\author{
S Bouralexis', DM Findlay', GJ Atkins', A Labrinidis', S Hay' and A Evdokiou*,I \\ 'Department of Orthopaedics and Trauma, University of Adelaide, Level 4, Bice Building, Royal Adelaide Hospital, North Terrace, Adelaide 5000, \\ South Australia, Australia
}

Apo2 ligand (Apo2L, also known as TRAIL) is a member of the tumour necrosis factor (TNF) family of cytokines that selectively induces the death of cancer cells, but not of normal cells. We observed that recombinant Apo2L/TRAIL was proapoptotic in earlypassage BTK-I 43 osteogenic sarcoma cells, inducing $80 \%$ cell death during a $24 \mathrm{~h}$ treatment period. Apo2L/TRAIL-induced apoptosis was blocked by caspase inhibition. With increasing passage in culture, BTK-I 43 cells became progressively resistant to the apoptotic effects of Apo2L/TRAIL. RNA and flow cytometric analysis demonstrated that resistance to Apo2L/TRAIL was paralleled by progressive acquisition of the decoy receptor, DcR2. Blocking of DcR2 function with a specific anti-DcR2 antibody restored sensitivity to Apo2L/TRAIL in a dose-dependent manner. Importantly, treatment of resistant cells with the chemotherapeutic agents doxorubicin, cisplatin and etoposide reversed the resistance to Apo2L/TRAIL, which was associated with drug-induced upregulation of mRNA encoding the death receptors DR4 and DR5. BTK-I 43 cells thus represent a useful model system to investigate both the mechanisms of acquisition of resistance of tumour cells to Apo2L/TRAIL and the use of conventional drugs and novel agents to overcome resistance to Apo2L/TRAIL.

British Journal of Cancer (2003) 89, 206-214. doi:I0.1038/sj.bjc.660I02I www.bjcancer.com

(c) 2003 Cancer Research UK

Keywords: DcR2; Apo2L/TRAIL; osteosarcoma; resistance; chemotherapy; apoptosis

Osteosarcoma is the most common primary malignancy of the skeleton. The first choice of treatment for osteosarcoma is preoperative chemotherapy (Seki et al, 2000). The agents doxorubicin (DOX), cisplatin (CDDP) and etoposide (ETP), and others such as cyclophosphamide, methotrexate and vincristine, are commonly used in combination therapy to target osteosarcoma (Bramwell, 2000; Seki et al, 2000). However, the use of chemotherapy is often associated with the frequent acquisition of drug-resistant phenotypes and the occurrence of 'second malignancies'. In addition, the associated cytotoxic side effects on normal tissues and organs represent a serious limitation to the use of these agents. Importantly, osteosarcomas are often resistant to the induction of apoptosis by anticancer agents (Seki et al, 2000), so that there is a pressing need to develop new and alternative approaches to the current chemical treatment of this tumour type.

Apo2L/TRAIL is a new member of the tumour necrosis factor (TNF)-cytokine family that induces cell death in a wide variety of tumour cell lines, but does not seem to be cytotoxic to many normal cell types in vitro or in vivo (Ashkenazi et al, 1999;

*Correspondence: Dr A Evdokiou;

E-mail: andreas.evdokiou@adelaide.edu.au

Received 29 November 2002; revised 7 April 2003; accepted 13 April 2003
Walczak et al, 1999; Atkins et al, 2002; Evdokiou et al, 2002). Apo2L/TRAIL is a type II transmembrane protein that induces apoptosis through interactions with its death domain-containing receptors, DR4/TRAIL-R1 and DR5/TRAIL-R2 (Pan et al, 1997a,b; Sheridan et al, 1997; Walczak et al, 1997). Ligand-dependent activation of DR4 and DR5 involves receptor multimerisation, with subsequent recruitment of the intracellular death adaptor molecule, Fas-associated death domain protein (FADD), that engages the initiator protease caspase- 8 (Newton et al, 2001). Fasassociated death domain protein triggers caspase- 8 autoactivation and subsequently leads to activation of downstream effector caspases, including caspase- 3 and caspase-7, resulting in the cleavage of cellular substrates and ultimately cell death by apoptosis (Nagata, 1997; Ashkenazi and Dixit, 1998). Death receptor activity can be antagonised by the so-called 'decoy' receptors for Apo2L/TRAIL, of which there are to date three known in the human: DcR1/TRAIL-R3/TRID (Degli-Esposti et al, 1997a,b), DcR2/TRAIL-R4/TRUNDD (Marsters et al, 1997; Pan et al, 1998; Degli-Esposti, 1999) and osteoprotegerin (OPG) (Emery et al, 1998). DcR1 and DcR2 lack functional death domains and cannot mediate apoptosis. Osteoprotegerin is a widely expressed soluble member of the TNF receptor family that is capable of binding to Apo2L/TRAIL and can block Apo2L/TRAIL-induced apoptosis (Emery et al, 1998), although its role in doing so has not been extensively explored. 
The relative levels of expression of death and decoy receptors suggests a possible mechanism, by which cells are rendered resistant to Apo2L/TRAIL, although the pattern of expression of Apo2L/TRAIL receptors does not necessarily correlate with resistance or sensitivity to Apo2L/TRAIL-mediated apoptosis (Degli-Esposti, 1999; Keane et al, 1999). Recent findings, which demonstrate that the death and decoy receptors for Apo2L/TRAIL have different subcellular locations and undergo redistribution within the cell following treatment with Apo2L/TRAIL (Zhang et al, $2000 \mathrm{a}, \mathrm{b})$, highlight other levels of complexity that determine Apo2L/TRAIL sensitivity. These, and other observations suggest that, in addition to Apo2L/TRAIL receptor expression and distribution, the cytotoxic effects of Apo2L/TRAIL are likely to be mediated by events involving the complex interplay between proapoptotic and prosurvival pathways (Roy and Nicholson, 2000).

Irrespective of the mechanisms that determine sensitivity or resistance, animal studies indicate that Apo2L/TRAIL has great therapeutic potential for many cancer types (Ashkenazi et al, 1999). Apo2L/TRAIL was demonstrated safe and nonimmunogenic (Ashkenazi et al, 1999; Walczak et al, 1999), was active alone in some cancer types (Ashkenazi et al, 1999) and exhibited synergistic activity with chemotherapeutic agents, causing marked regression or complete remission of tumours (Ashkenazi et al, 1999; Walczak et al, 1999). However, some tumour types are resistant to Apo2L/TRAIL-induced apoptosis (Bin et al, 2002), while it has been reported that melanoma cells are frequently resistant at the time of surgical excision, but regain sensitivity in cell culture (Nguyen et al, 2001). It is therefore important to develop an understanding of the factors that lead to sensitivity or resistance of tumour cells to Apo2L/TRAIL.

Using a panel of human osteosarcoma cell lines, we recently observed resistance of this type of tumour cell to Apo2L/TRAIL, which could be overcome by cotreatment with chemotherapeutic agents (Evdokiou et al, 2002). However, we observed initially that recombinant Apo2L/TRAIL was proapoptotic in one cell line, the BTK-143 osteosarcoma cell line. The present study found that with repeated passage in culture, BTK-143 cells became progressively resistant to the apoptotic effects of Apo2L/TRAIL. Further analysis revealed that there was a significant increase in the expression of DcR2 with repeated passage, which paralleled with a loss of sensitivity to Apo2L/TRAIL, and suggested a role for DcR2 in determining resistance to Apo2L/TRAIL-induced apoptosis. Importantly, treatment of the late passage resistant cells with DOX, CDDP or ETP reversed the resistance to Apo2L/TRAIL and sensitised late passage cells to Apo2L/TRAIL-induced apoptosis. These cells therefore represent a useful model system to investigate the mechanisms of acquisition of resistance of tumour cells to Apo2L/TRAIL and those by which resistance may be overcome.

\section{MATERIALS AND METHODS}

\section{Cells and reagents}

The BTK-143 osteogenic sarcoma cell line was obtained from the American Type Culture Collection (ATCC, Rockville, MD, USA) and cultured in Dulbecco's modified Eagle's medium (DMEM), supplemented with glutamine $(2 \mathrm{mM})$, penicillin $\left(100 \mathrm{IU} \mathrm{ml}^{-1}\right)$, streptomycin $\left(100 \mu \mathrm{g} \mathrm{ml}^{-1}\right)$, gentamicin $\left(160 \mu \mathrm{g} \mathrm{ml}^{-1}\right)$ and $10 \%$ foetal bovine serum (Biosciences, Sydney, Australia). Cultures were grown in a humidified atmosphere containing $5 \% \mathrm{CO}_{2}$. The cells were passaged every $3-4$ days, after reaching $80 \%$ confluency, into $\mathrm{T} 75 \mathrm{~cm}^{2}$ tissue culture flasks (Corning, Costar Corp., Cambridge, MA, USA). Nontagged homotrimeric Apo2L/TRAIL was generously provided by Genentech, Inc. (South San Francisco, CA, USA). Doxorubicin, CDDP, and ETP were obtained from Pharmacia \& Upjohn (Kalamazoo, MI, USA). The tetrapeptide caspase inhibitors ZVAD-fmk and ZDEVD-fmk were purchased from Calbiochem (Alexandria, NSW, Australia).

\section{Measurement of cell number}

To determine effects on cell number, $2.5 \times 10^{4}$ cells per well were seeded in 48-well microtitre plates and allowed to adhere to the plate overnight. Cells were then treated for $24 \mathrm{~h}$ with $100 \mathrm{ng} \mathrm{ml}^{-1}$ of soluble recombinant Apo2L/TRAIL. Cell number was determined by staining the cells with crystal violet and measuring $\mathrm{OD}_{570 \mathrm{~nm}}$ of cell lysates. To assess the effects of chemotherapeutic agents on Apo2L/TRAIL-mediated effects on cell number, cells were plated in 48-well plates and allowed to adhere for 24-48 h. Doxorubicin, CDDP or ETP were added to the wells at the indicated concentrations either alone, or in combination with $100 \mathrm{ng} \mathrm{ml}^{-1}$ of Apo2L/TRAIL, and incubated for $24 \mathrm{~h}$. Cell number was again determined by staining the cells with crystal violet. All cell number experiments were performed in triplicate or quadruplicate and experiments were repeated at least three times. Results of representative experiments are given as the mean \pm s.d.

\section{Reverse transcription-polymerase chain reaction analysis}

RNA was extracted from cells using the Trizol Reagent (Invitrogen, Groningen, Netherlands), as recommended by the supplier. Firststrand complementary DNA (cDNA) was synthesised from $2.0 \mu \mathrm{g}$ of total RNA in a final volume of $20 \mu \mathrm{l}$ using SuperScript II (Life Invitrogen, $\mathrm{BV} \mathrm{CH}$, Groningen, the Netherlands) and random primers (Bresagen Inc., Adelaide, South Australia). cDNA (1.0 $\mu \mathrm{l}$ out of $20 \mu \mathrm{l}$ ) was then amplified by polymerase chain reaction (PCR) using specific primers corresponding to mRNA encoding human gene products as outlined in Table 1 . The $20 \mu \mathrm{l}$ amplification mixture contained $1 \mathrm{U}$ of AmpliTaq Gold DNA polymerase (Perkin Elmer, Norwalk, CT, USA), $100 \mathrm{ng}$ each of the $5^{\prime}$ and $3^{\prime}$ primers, $0.2 \mathrm{mM}$ dNTPs (Pharmacia Biotech, Uppsala, Sweden), $1.5 \mathrm{mM} \mathrm{MgCl} 2,2 \mu \mathrm{l} 10 \times$ reaction buffer and sterile DEPC- $\mathrm{H}_{2} \mathrm{O}$. Polymerase chain reaction was performed for 23 cycles for GAPDH and 30-35 cycles for other primer pairs, such that all products could be assayed in the exponential phase of the amplification curve, in a thermal cycler (Corbett Research, Melbourne, Victoria, Australia). After an initial step at $95^{\circ} \mathrm{C}$ for $9 \mathrm{~min}$ to activate the polymerase, each cycle consisted of $1 \mathrm{~min}$ of denaturation at $94^{\circ} \mathrm{C}, 1 \mathrm{~min}$ of annealing at the temperatures indicated in Table 1 , and $1 \mathrm{~min}$ of extension at $72^{\circ} \mathrm{C}$. This was followed by an additional extension step at $72^{\circ} \mathrm{C}$ for $1 \mathrm{~min}$. Primer sequences and predicted PCR product sizes are shown in Table 1. Amplification products were resolved by electrophoresis on a $2 \%$ $\mathrm{wv}^{-1}$ agarose gel and poststained with SYBR-1 Gold (Molecular Probes, Eugene, OR, USA). The relative amounts of the PCR products were determined by quantifying the intensity of bands using a FluorImager and ImageQuant software (Molecular Dynamics, Sunnyvale, CA, USA). Amplified products are represented as a ratio of the respective PCR product/GAPDH PCR product. To show that there were no false-positive results, PCR reactions were carried out using nonreverse transcribed RNA, and on reaction mixtures to which no RNA was added.

\section{Measurement of DEVD-caspase like activity}

DEVD-caspase-3 like activity was assayed by cleavage of zDEVDAFC (z-asp-glu-val-asp-7-amino-4-trifluoro-methyl-coumarin), a fluorogenic substrate based on the peptide sequence at the caspase- 3 cleavage site of poly (ADP-ribose) polymerase (Medina et al, 1997). Cells $\left(2.5 \times 10^{4}\right)$ grown in 48 -well plates were treated as indicated, washed once with HBSS and resuspended in $200 \mu \mathrm{l}$ of NP-40 lysis buffer containing $5 \mathrm{~mm}$ Tris- $\mathrm{HCl}, 5 \mathrm{~mm}$ EDTA and $0.5 \%$ $\mathrm{NP}-40, \mathrm{pH}$ 7.5. After $15 \mathrm{~min}$ in lysis buffer at $4^{\circ} \mathrm{C}$, insoluble material was pelleted at $15000 \mathrm{~g}$ and an aliquot of the lysate was 
Table I PCR primers and conditions for the specific amplification by RT-PCR of human mRNA species

\begin{tabular}{|c|c|c|c|}
\hline Target gene & Primer sequences sense (S), antisense (AS) & $\begin{array}{c}\text { Annealing } \\
\text { temperature }(\mathrm{C})\end{array}$ & $\begin{array}{l}\text { Product } \\
\text { size (kb) }\end{array}$ \\
\hline DR4 & $\begin{array}{l}\text { S 5'-TGCTGCAGCTCGTACCTAGCTC-3' } \\
\text { AS 5'-TTGCTGCTCAGAGACGAAAGTGG-3' }\end{array}$ & 66 & 646 \\
\hline DR5 & $\begin{array}{l}\text { S 5'-CTGCAACTGTGACTCCTATG-3' } \\
\text { AS 5'-GTCTGCTCTGATCACCCAAC-3' }\end{array}$ & 66 & 424 \\
\hline DcRI & $\begin{array}{l}\text { S 5'-TCCTAGCTTACTCTGCCACCACT-3' } \\
\text { AS 5'-CACAATTAGAACTATGATCCCTACG-3' }\end{array}$ & 66 & 700 \\
\hline DcR2 & $\begin{array}{l}\text { S 5'-TTCTCATGGGACTTTGGGGACAA-3' } \\
\text { AS 5 5'-CTGTTACTCAGGGTCTCGTTGC-3' }\end{array}$ & 66 & 855 \\
\hline OPG & $\begin{array}{l}\text { S 5'-TGCTGTTCCTACAAAGTTAC-3' } \\
\text { AS 5'-CTTTGAGTGCTTAGTGCGTG-3' }\end{array}$ & 62 & 435 \\
\hline FLIP & $\begin{array}{l}\text { S 5'-AATTCAAGGCTCAGAAGCGA-3' } \\
\text { AS 5 5'-GGCAGAAACTCTGCTGTTCC-3' }\end{array}$ & 62 & 229 \\
\hline GAPDH & $\begin{array}{l}\text { S 5'-CATGGAGAAGGCTGGGGCTC-3' } \\
\text { AS 5'-CACTGACACGTTGGCAGTGG-3' }\end{array}$ & 62 & 414 \\
\hline
\end{tabular}

$\mathrm{S}=$ sense primers; $\mathrm{AS}=$ antisense primers. Annealing temperatures were determined empirically using AmpliTaq Gold (Perkin Elmer) in a gradient thermal cycler (Corbett Research).

tested for protease activity. To each assay tube containing $8 \mu \mathrm{M}$ of substrate in $1 \mathrm{ml}$ of protease buffer (50 mM HEPES, $10 \%$ sucrose, 10 mm DTT, $0.1 \%$ CHAPS, pH 7.4), was added to $20 \mu \mathrm{l}$ of cell lysate. Reactions were allowed to proceed for $4 \mathrm{~h}$ at room temperature in total darkness, whereupon fluorescence was quantified (Exc 400, Emis 505) in a Perkin-Elmer LS50 spectrofluorimeter. Optimal amounts of added lysate and duration of assay were taken from linear portions of curves as determined in preliminary experiments. One unit of caspase activity was taken as one fluorescence unit (at slit widths of $12.5 \mathrm{~nm}$ ) per $4 \mathrm{~h}$ incubation with substrate.

The tetrapeptide caspase inhibitors ZVAD-fmk, and ZDEVDfmk were resuspended in DMSO (Sigma-Aldrich, Castle Hill, NSW, Australia) and were added to cells at the indicated concentrations 30 min before treatment with Apo2L/TRAIL. Control cells were incubated with the equivalent concentration of DMSO.

\section{4',6-diamidine-2'-phenylindole dihydrochloride staining of nuclei}

Cells were seeded on plastic chamber slides and treated as indicated. After two washes with phosphate-buffered saline (PBS), cells were fixed in an ethanol/acetic acid solution (six parts ethanol : one part acetic acid) for $10 \mathrm{~min}$, washed again with PBS, and allowed to air-dry overnight. The chamber slides were then incubated with $0.8 \mu \mathrm{g} \mathrm{ml}^{-1}$ of $4^{\prime}$,6-diamidine- $2^{\prime}$-phenylindole dihydrochloride (DAPI), (Roche Diagnostics, Castle Hill, NSW, Australia) in PBS for 2-5 min in the dark and at room temperature. After several washes in PBS, the coverslips were mounted with $n$-propyl gallate (antifade, Sigma Chemical Company, St Louis, MO, USA). 4',6-diamidine- $2^{\prime}$-phenylindole dihydrochloride staining was visualised by fluorescence microscopy.

\section{Flow cytometric analysis}

For flow cytometric analysis, cells were seeded into fresh culture flasks 1 day prior to the assay, rinsed twice with PBS and detached using $2 \mathrm{~mm}$ EDTA in $\mathrm{PBS}$ at $37^{\circ} \mathrm{C}$ for $5 \mathrm{~min}$. All subsequent incubation steps were performed on ice and centrifugation steps were performed at $4^{\circ} \mathrm{C}$. Cells were washed twice in PBS by centrifugation at $200 \mathrm{~g}$ for $5 \mathrm{~min}$, resuspended at $2 \times 10^{6} \mathrm{cell} \mathrm{ml}^{-1}$ in blocking buffer (10\% BSA/PBS $+0.1 \%$ azide $)$ and $50 \mu$ laliquots of the cell suspensions were added to polypropylene FACS tubes. To each of these was added $50 \mu \mathrm{l}$ of monoclonal antibody solution (Mab) specific for human TRAIL receptors TR1, TR2, TR3, TR4 (Zhang et al, 2000a,b) (supplied by Immunex Corp., Seattle, WA, USA) or isotype-matched nonbinding control Mabs (provided by Dr Leonie Ashman, University of Newcastle, NSW, Australia), each diluted to $10 \mu \mathrm{g} \mathrm{ml}^{-1}$ in blocking buffer. After incubation for $45 \mathrm{~min}$, the cells were washed twice in wash buffer by centrifugation at $300 \mathrm{~g}$. To the resuspended cell pellets was added $50 \mu \mathrm{l}$ of FITC-labelled $\mathrm{F}\left(\mathrm{ab}^{\prime}\right)_{2}$ sheep anti-mouse Ig or goat anti-mouse IgGPE (Southern Biotechnology, Birmingham, AL, USA), both diluted 1:50 in blocking buffer. The cells were incubated for a further $45 \mathrm{~min}$ in the dark, washed twice as above, then resuspended and fixed in $0.5 \mathrm{ml}$ of cold $1 \% \mathrm{wv}^{-1}$ paraformaldehyde for analysis by flow cytometry.

\section{In situ immunofluorescence}

Cells were seeded into 8-chamber slides (Nunc, Inc., Naperville, IL, USA) at $1 \times 10^{4}$ cells per well, and cultured for $24 \mathrm{~h}$. In situ immunofluorescence was performed at room temperature. Cells were rinsed once in PBS, fixed in $2 \%$ paraformaldehyde in PBS for $5 \mathrm{~min}$, and permeabilised with $0.1 \%$ saponin in PBS containing $10 \%$ heat-inactivated pooled normal human serum (permeabilisation buffer), for $10 \mathrm{~min}$. The cells were then washed thrice with PBS containing $0.1 \%$ bovine serum albumin (BSA) and $0.1 \% \mathrm{NaN}_{3}$ (wash buffer), and blocked in 5\% normal goat serum (NGS) containing $0.1 \% \mathrm{w} \mathrm{v}^{-1} \mathrm{NaN}_{3}$ (blocking buffer) for $60 \mathrm{~min}$. The blocking buffer was removed and monoclonal antibodies (Mab) specific for human TRAIL receptors TR1, TR2, TR3, TR4 (as above), OPG (Mab 8051 or isotype-matched nonbinding control Mabs (as above), each diluted to $10 \mu \mathrm{g} \mathrm{ml}^{-1}$ in blocking buffer as above, were added for $60 \mathrm{~min}$. The slides were washed thrice in PBS containing $0.05 \%\left(\mathrm{v} \mathrm{v}^{-1}\right)$ Triton X-100. To reveal primary antibody reactivity, cells were incubated for a further $60 \mathrm{~min}$ in the dark, with a 1:30 dilution in PBS of FITC-conjugated goat anti-mouse $\mathrm{F}\left(\mathrm{ab}^{\prime}\right)_{2}$. The cells were washed thrice as above, then resuspended and fixed in $0.2 \mathrm{ml}$ of cold $1 \% \mathrm{w} \mathrm{v}^{-1}$ paraformaldehyde for analysis. The labelled samples were mounted in Univert mountant and examined using an Olympus Bx 51 fluorescence microscope and imaged using a Photometrics Coolsnap Fx digital camera (Roper Scientific, NJ, USA).

\section{Inhibition of function of DcR2}

Cells were seeded at $2.5 \times 10^{4}$ cells per well in 48 -well microtitre plates and allowed to adhere overnight. The cells were then cultured in DMEM (as above) with increasing concentrations of anti-DcR2 antibody or an isotype matched negative control antibody (as above), of up to $100 \mu \mathrm{g} \mathrm{ml}^{-1}$ for a period of $24 \mathrm{~h}$. Culture media were then removed and the cells treated for a following $24 \mathrm{~h}$ with $100 \mathrm{ng} \mathrm{ml}^{-1}$ of recombinant soluble Apo2L/ TRAIL. 
Cell numbers were determined by staining the cells with crystal violet and measuring $\mathrm{OD}_{570 \mathrm{~nm}}$ of cell lysates, as we have described previously (Evdokiou et al, 2002). In some experiments, relative cell numbers were also ascertained by staining with WST-1 (Roche Diagnostics, Mannheim, Germany), which gave identical results to those obtained with crystal violet (data not shown). All cell proliferation experiments were performed in triplicate and experiments were repeated at least three times. Results of representative experiments are given as the mean \pm s.d.

\section{RESULTS}

Sensitivity of BTK-143 osteosarcoma cells to recombinant soluble Apo2L/TRAIL

Treatment of BTK-143 cells with recombinant Apo2L/TRAIL, at a concentration of $100 \mathrm{ng} \mathrm{ml}^{-1}$ for $24 \mathrm{~h}$, resulted in a considerable reduction in cell number, with $80 \%$ cell death compared with untreated control cells (Figure 1A). Morphological changes characteristic of apoptosis, including chromatin condensation, nuclear fragmentation and the formation of dense rounded apoptotic bodies, were evident in a high percentage of the Apo2L/TRAIL-treated cells following DAPI staining (Figure 1B). The onset of apoptosis following treatment with Apo2L/TRAIL was concomitant with a seven-fold increase in the level of caspase-3like activity (Figure 1C). The pan-caspase inhibitor, zVAD-fmk, and the caspase-3-specific inhibitor, zDEVD-fmk completely prevented the Apo2L/TRAIL-induced apoptosis confirming the role of caspase activation in Apo2L/TRAIL-mediated apoptosis of BTK-143 cells (Figure 1D).

With repeated passage in culture, we found that BTK-143 cells became progressively resistant to the apoptotic effects of Apo2L/ TRAIL. For example, at passage 2, treatment of these cells for $24 \mathrm{~h}$ resulted in $80 \%$ cell deaths (Figure $2 \mathrm{~A}$ ). By passage 5 , only $60 \%$ of the cells were responsive and at passage 10 only $20 \%$ of the cells
A

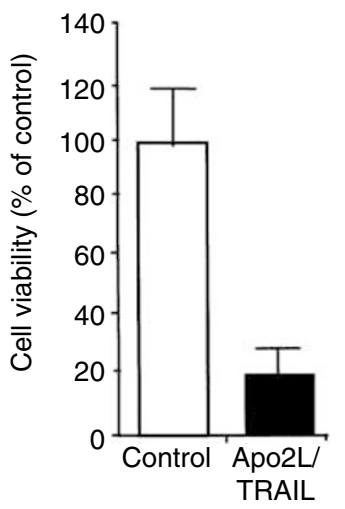

C

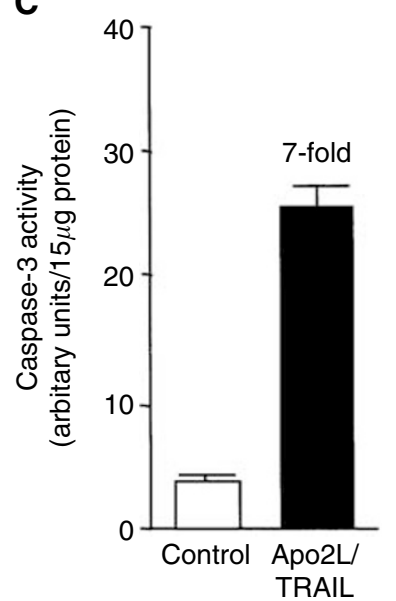

B

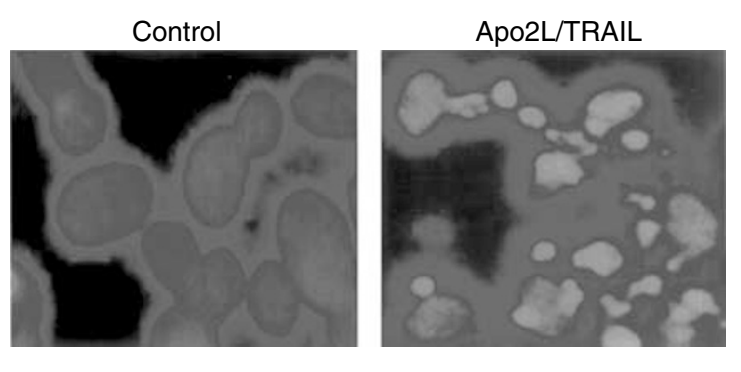

D

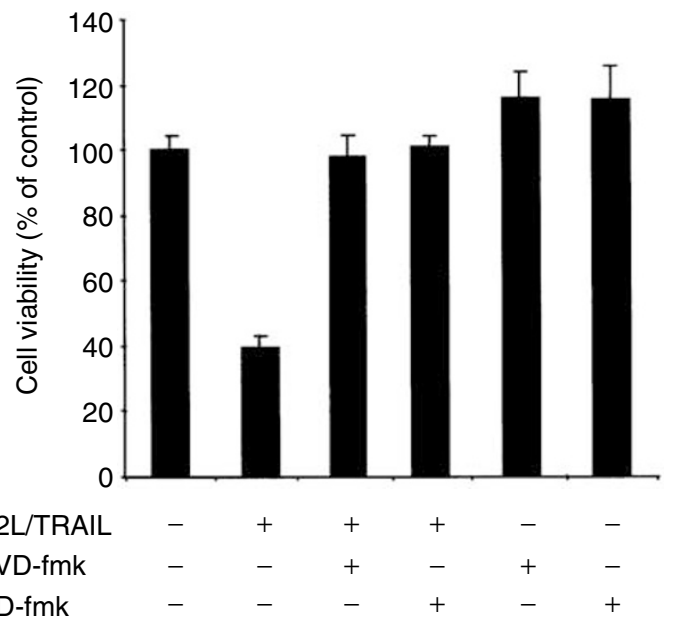

Figure I Apo2L/TRAIL-induced apoptosis in BTK-I43 cells. (A) BTK-I43 osteosarcoma cells (I.5 $\left.\times 10^{4}\right)$ were seeded into triplicate wells of a 48-well plate. Cells were incubated for $24 \mathrm{~h}$ in the absence (white bar) or presence of $100 \mathrm{ng} \mathrm{m}^{-1}$ of soluble recombinant Apo2L/TRAIL (black bar). Cell number was assessed by crystal violet staining and the results are given as a percentage of control, untreated cells. Data shown are means of triplicate wells \pm s.d. and are representative of experiments repeated at least three times. (B) DAPI nuclear fluorescence stain, showing changes in the nuclei of Apo2L/TRAIL-treated BTK-I43 cells consistent with induction of apoptosis. Left panel: Control, untreated cells showing homogeneously fluorescent nuclei. Right panel: Cells treated for $24 \mathrm{~h}$ with $100 \mathrm{ng} \mathrm{ml}^{-1}$ Apo2L/TRAIL; note the presence of apoptotic bodies containing condensed chromatin. (C) Caspase-3-like activity in BTK143 cells incubated in the absence (white bar) or treated for $24 \mathrm{~h}$ with $100 \mathrm{ng} \mathrm{m}^{-1}$ of Apo2L/TRAlL (black bar). Activity was determined in cell lysates using the caspase-3-specific fluorogenic substrate, zDEVD-AFC, as described in the Methods. Data shown are representative of three independent experiments: bars, \pm s.d. (D) Effect of caspase inhibitors on Apo2L/TRAlL-treated BTK-I43 cells. Cells were treated for $24 \mathrm{~h}$ with I00 ng ml ${ }^{-1}$ of Apo2L/TRAIL alone or with Apo2L/TRAIL and either the pan-caspase inhibitor zVAD-fmk (50 $\mu \mathrm{M})$ or the caspase-3 specific inhibitor zDEVD-fmk (50 $\mu \mathrm{M})$. Cells were also treated with each inhibitor alone. Cell viability is expressed as a percentage of control untreated cells. Data are means of triplicate results from a representative experiment repeated at least three times; bars, \pm s.d. 


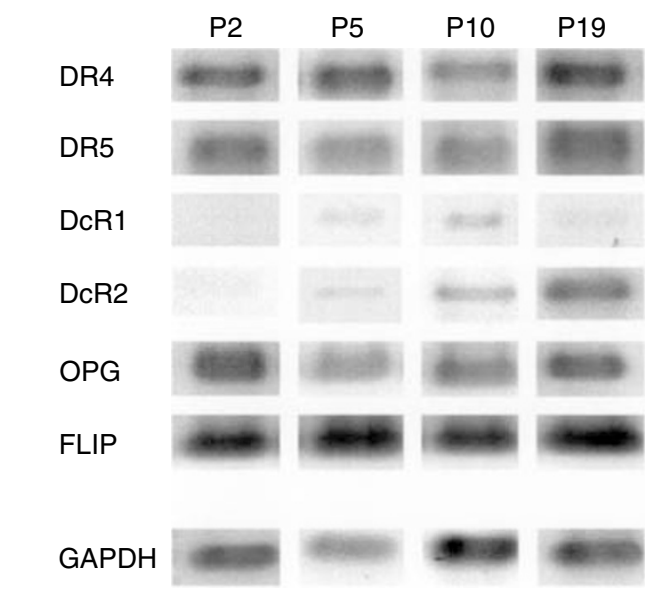

в
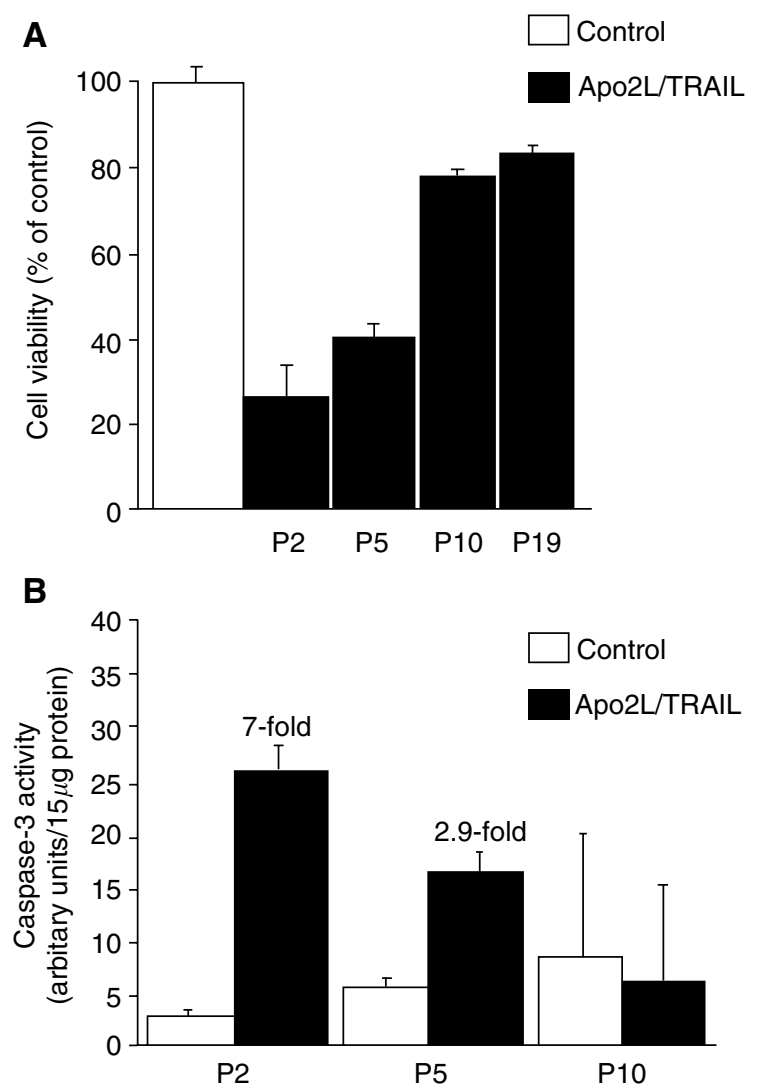

Figure 3 Reverse transcriptase-polymerase chain reaction analysis of Apo2L/TRAIL receptor mRNA expression patterns in BTK-I 43 osteosarcoma cell line with increasing passage. Analysis of steady-state Apo2L/ TRAIL receptor mRNA expression in the BTK-I43 osteosarcoma cells, assessed by semiquantitative RT-PCR analysis, as described in the Materials and methods. Expression of the housekeeping gene, GAPDH, served to normalise for starting mRNA. The panel shows the pattern of Apo2L/TRAIL receptor expression with increase in passage $(P)$ number. Note the strong expression of DcR2 at PI9.

Figure 2 Repeated passage of BTK-I 43 cells leads to resistance to Apo2L/TRAIL-induced apoptosis and loss of caspase activation. Apo2L TRAIL-sensitive BTK-I 43 cells were treated for $24 \mathrm{~h}$ with $100 \mathrm{ng} \mathrm{ml}^{-1}$ of Apo2L/TRAIL. (A) Cell number, represented as a function of total protein stained with crystal violet, is shown as a percentage of control untreated cells for the passage (P) numbers indicated. (B) Caspase-3-like activity in cell lysates prepared from control or Apo2L/TRAlL-treated cells, as indicated. Caspase-3-like activity was determined using the caspase-3 specific fluorogenic substrate, zDEVD-AFC, as described in the Materials and Methods. Results represent caspase activation per $15 \mu \mathrm{g}$ lysate protein. Data are means of triplicate results from a representative experiment repeated at least three times; bars, \pm s.d.

were responsive to Apo2L/TRAIL, which remained the case at least up to passage 19 (Figure 2A). Assessment of caspase-3-like protease activity demonstrated a gradual decrease in the level of caspase- 3 activation by Apo2L/TRAIL as the passage number increased (Figure 2B).

\section{Apo2L/TRAIL receptor mRNA expression and Apo2L/TRAIL sensitivity}

To determine whether there were any changes in Apo2L/TRAIL receptor expression with passage number in BTK-143 cells, semiquantitative reverse transcriptase-polymerase chain reaction (RT-PCR) analysis was performed to amplify mRNA corresponding to each of the Apo2L/TRAIL receptors. Preliminary experiments were performed to ensure that the number of PCR cycles used in each case was within the linear phase of each amplification curve (data not shown). Reverse transcriptase-polymerase chain reaction analysis of BTK-143 cells at passage 2, 5, 10 and 19 revealed that the mRNA level of the death receptors, DR4 and DR5, did not notably change with passage (Figure 3 ). However, with increasing passage number, the level of mRNA corresponding to decoy receptors, DcR1 and DcR2, increased markedly, with the effect on DcR2 expression being more pronounced (Figure 3). At passage 2, there was little or no detectable DcR1 mRNA and this increased to readily detectable levels by passage 10 . More dramatically, the level of DcR2 mRNA progressively increased from undetectable levels at early passage to high levels at later passage (Figure 3). It has been suggested that sensitivity to Apo2L/ TRAIL might be explained by downstream components of the Apo2L/TRAIL apoptotic pathway. We therefore examined whether there was any change in the steady-state level of FLIP mRNA (a known inhibitor of the Apo2L/TRAIL apoptotic pathway), between early-passage (sensitive) and late-passage (resistant) cells. Reverse transcriptase-polymerase chain reaction analysis demonstrated that the BTK-143 cells expressed high levels of FLIP mRNA, which did not significantly change with increasing passage number (Figure 3).

To assess the expression of Apo2L/TRAIL receptors at the protein level, we performed flow cytometric analysis on intact cells using specific antibodies to each of the receptors. Our results clearly demonstrated that cell surface expression of DcR2 increased with passage, and confirmed the data we obtained with RT - PCR analysis (Figure 4A). There were no detectable changes in the cell surface expression of either of the two death receptors, DR4 and DR5, or the other decoy receptor, DcR1. Immunofluorescence labelling with an antibody directed against DcR2 demonstrated a significantly higher level of DcR2 receptor expression in the late-passaged cells when compared to early-passaged cells. The $1 \mathrm{~B} 5$ isotype-matched (IgG1) murine monoclonal antibody was used as a negative control (Figure 4B). The expression of DcR 2 was predominantly cytoplasmic, with strong expression also at the cell surface. To assess whether the acquired resistance to Apo2L/ TRAIL was attributable to the gain in DcR2 expression, blocking antibodies against DcR2 were used in late passage, resistant BTK143 cells. Preincubation of late-passage cells in the presence of increasing concentrations of the anti-DcR2 monoclonal antibody for a period of $24 \mathrm{~h}$ restored in a dose-dependent manner their sensitivity to Apo2L/TRAIL-induced apoptosis (Figure 5), whereas incubation of the cells with an isotype-matched negative control monoclonal antibody had no effect (data not shown). Taken together, these results suggest that the gain of DcR2 expression confers protection from Apo2L/TRAIL-induced apoptosis in these cells. 


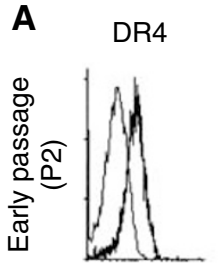

DR5
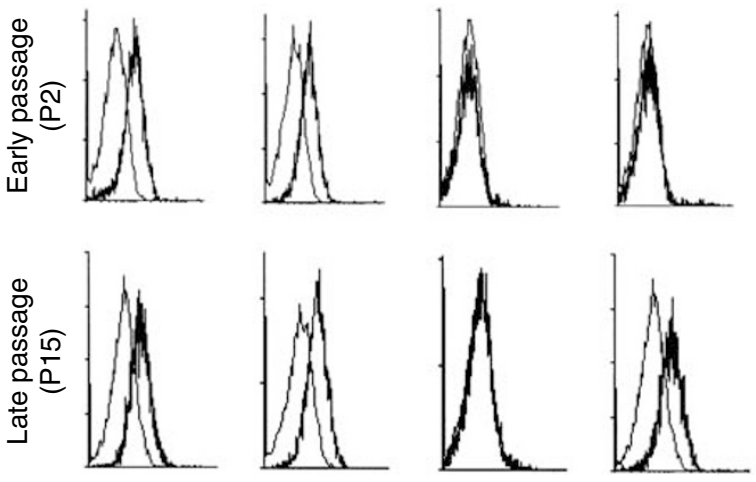

B

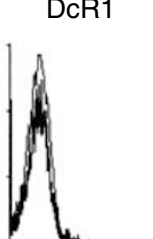

DcR2

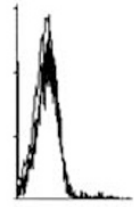

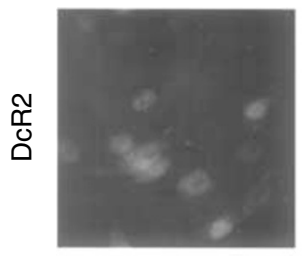
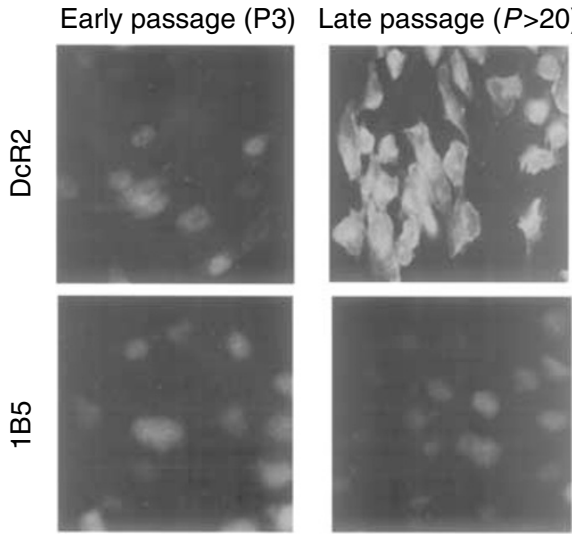

Figure 4 Cell surface expression of Apo2L/TRAIL receptors detected by flow cytometric analysis and in situ immunofluorescence staining. (A) Flow cytometric data of cell surface expression of Apo2L/TRAlL receptors shows strong expression of DcR2 by late-passage ( $/ 5)$ cells, compared with early-passage (P2) cells (heavy line). The IB5 isotype-matched (IgGI) murine monoclonal antibody was used as a negative control (light line). These results are from a representative experiment repeated at least three times. (B) In situ immunofluorescence of DcR2 in early-(P3) and latepassage $(P>20)$ BTK-I 43 cells. Note the strong expression of DcR2 at the cell surface and within the cytoplasm of the late-passage cells, compared with the weak or absent staining of early-passage (P3) cells. The IB5 isotype-matched $(\mid \mathrm{gGl})$ murine monoclonal antibody shows only weak staining that is no different between early- and late-passaged cells.

\section{Chemotherapy sensitises resistant BTK-143 cells to Apo2L/TRAIL/-induced apoptosis}

Several reports (Gliniak and Le, 1999; Desjosez et al, 2000; Gibson et al, 2000; Nagane et al, 2000; Yamanaka et al, 2000; Lacour et al, 2001; Mizutani et al, 2001), including our own (Evdokiou et al, 2002), have demonstrated that chemotherapeutic drugs augment Apo2L/TRAIL-induced apoptosis of sensitive, and more importantly Apo2L/TRAIL-resistant, cancer cells. Experiments were performed to determine whether combinations of Apo2L/TRAIL with chemotherapeutic agents clinically relevant for the treatment of osteosarcoma, including DOX, CDDP or ETP, could reverse the acquired resistance to Apo2L/TRAIL. The concentration of each agent used in the combined treatment with Apo2L/TRAIL was determined from dose-response curves, and was based on a concentration at which no more than $25 \%$ cell death was obtained over a $24 \mathrm{~h}$ treatment period (data not shown). The concentrations used in these experiments were as follows: DOX $2.0 \mu \mathrm{M}$, CDDP $12.5 \mu \mathrm{M}$ and ETP $50 \mu \mathrm{M}$. Cell viability data (expressed as a percentage of untreated cells), for late-passage (passage 19) BTK143 cells, incubated with drug alone, or in combination with

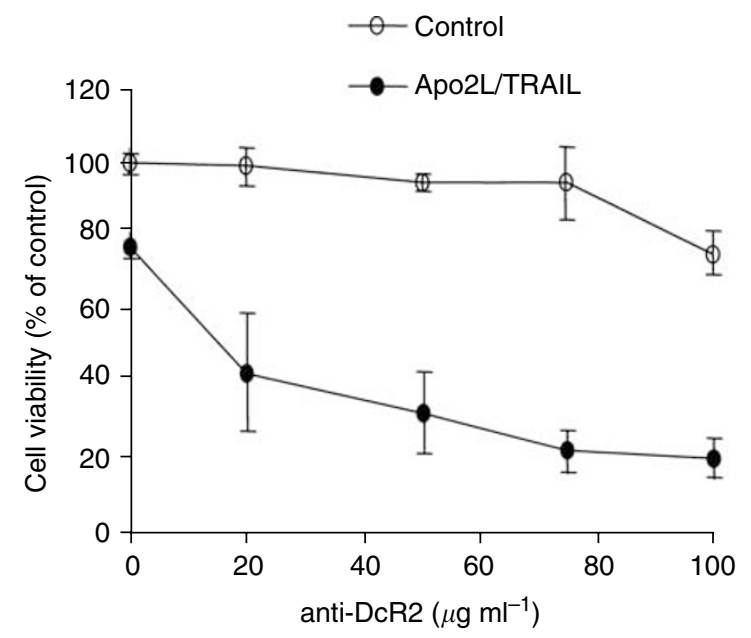

Figure 5 Effect of blocking the function of DcR2 using a specific antiDcR2 antibody. Cells were incubated with DcR2 antibody alone at increasing concentrations as indicated (open circles) or with anti-DcR2 antibody followed by incubation with $100 \mathrm{ng} \mathrm{ml}^{-1}$ recombinant Apo2L TRAIL (closed circles). Blocking of DcR2 resulted in a dose-dependent resensitisation to Apo2L/TRAIL-induced apoptosis in the late-passageresistant BTK-I43 cells (closed circles) compared with DCR2 antibody treatment alone (open circles). Viability is expressed as a percentage of the viability of untreated control cells. An isotype-matched negative control antibody titrated in a similar manner with Apo2L/TRAIL had no effect (data not shown).

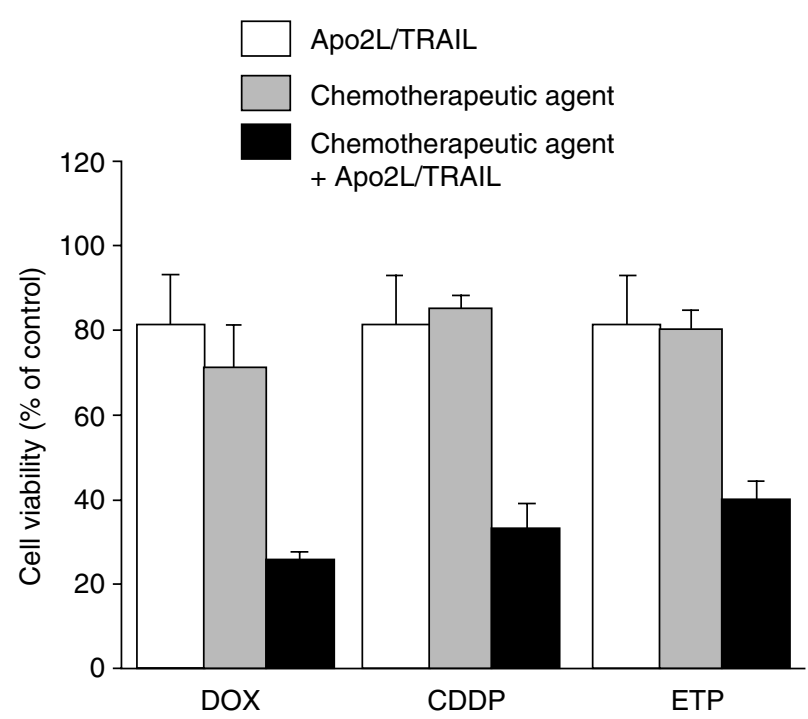

Figure 6 Chemotherapeutic agents DOX, CDDP and ETP sensitised resistant-late passage BTK-143 osteosarcoma cells to Apo2L/TRAILinduced apoptosis. Passage 19 BTK-143 cells were seeded into multiwell plates, as described for Figure I, and incubated with Apo2L/TRAIL $(100 \mathrm{ng} \mathrm{ml})$ alone, with sublethal doses of chemotherapeutic agent $(2.0 \mu \mathrm{M}$ DOX, $12.5 \mu \mathrm{m}$ CDDP and $50 \mu \mathrm{m}$ ETP) alone, or with Apo2L/TRAIL and drug in combination. Cell viability is shown as a percentage of untreated cells after $24 \mathrm{~h}$ treatment with Apo2L/TRAIL alone (white bars), drug alone (grey bars), or the combination of drug and Apo2L/TRAlL (black bars). Data points show means of quadruplicate results from a representative experiment, which was repeated three times; bars, \pm s.d.

Apo2L/TRAIL, are shown in Figure 6. While neither Apo2L/TRAIL alone nor chemotherapeutic agent alone had an appreciable effect on late-passage BTK-143 cells, each of the chemotherapeutic agents in combination with Apo2L/TRAIL resulted in a significant 
increase in cell death, representing a reversal of the resistant state of these cells. Reverse transcriptase-polymerase chain reaction analysis of cells following these treatments did not show any change in the expression of either DcR1 or DcR2 mRNA. However, we found that sensitisation of resistant late passage BTK-143 cells to Apo2L/TRAIL-induced apoptosis by these agents was accompanied by a drug-induced upregulation of both DR4 and DR5 death receptors. Figure 7A shows an increase in the expression of DR4 and DR5 mRNA upon treatment with ETP over a $24 \mathrm{~h}$ period. Similarly, flow cytometric analysis of intact cells, using specific antibodies directed against each of the receptors, clearly demonstrated that expression of DR4 and DR5 was significantly increased following treatment with ETP, whereas expression of DcR1 and DcR2 remained unchanged (Figure 7B). These results confirm the data we obtained with RT-PCR analysis. Resensitisation to Apo2L/ TRAIL was also accompanied by an increase in the level of FLIP mRNA (Figure 7A). These data are reminiscent of our previously published work showing that anticancer agents, including ETP, DOX and CDDP, upregulate expression of DR4 and/or DR5 in other osteosarcoma cell lines that are normally resistant to Apo2L/ TRAIL and can sensitise these cells to the apoptotic effects of the ligand (Evdokiou et al, 2002). In addition, our recent findings in normal human osteoblasts, in which proapoptotic and protective components of the Apo2L/TRAIL machinery appear to be coregulated in response to drugs such as ETP (Atkins et al, 2002), suggests that it is the balance of expression of these opposing influences that determines the outcome of exposure to Apo2L/TRAIL. These results show that resistance to Apo2L/ TRAIL-induced apoptosis in BTK-143 cells can be overcome with the use of conventional chemotherapeutic agents, and suggest that this may be due at least partly to increased expression of death receptors.

\section{DISCUSSION}

Osteosarcoma accounts for a high percentage of primary malignant tumours of bone. Treatment regimens have been developed in the last decade using cytotoxic chemotherapeutic drugs, which deliver significantly improved prognoses, particularly in younger patients. However, the toxicity of conventional chemotherapy limits its usefulness in older patients. Apo2L/TRAIL has been shown to specifically promote apoptosis in a wide variety of cancer cell types, and has hence been the subject of intense study in recent years.

Apo2L/TRAIL is able to induce apoptosis in a caspasedependent manner via the activation of death receptors (DR4 and DR5). The mechanisms of differential sensitivity to Apo2L/ TRAIL of different tumour types, or between tumours of the same type, are not well understood. However, there appear to be multiple mechanisms that apply, including increased expression of the decoy receptors for Apo2L/TRAIL (Griffith et al, 1998; Degli-
A

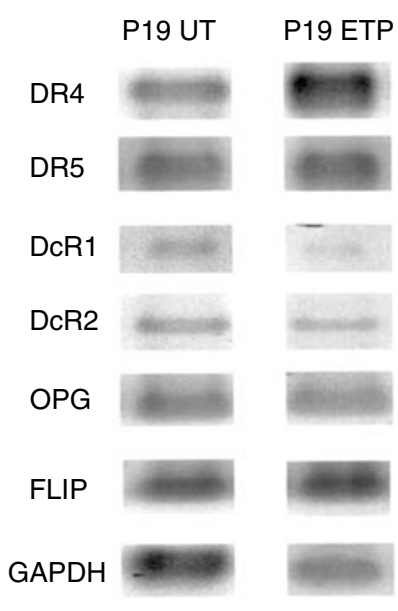

B

DR4

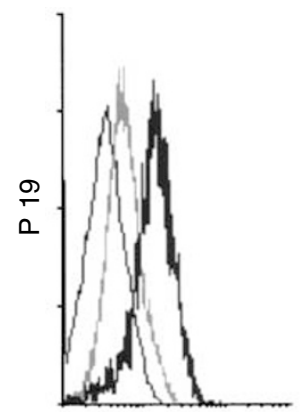

DR5

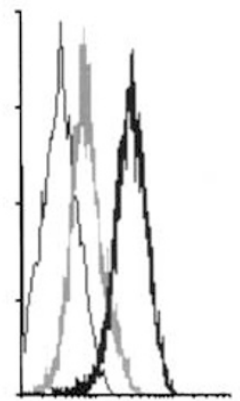

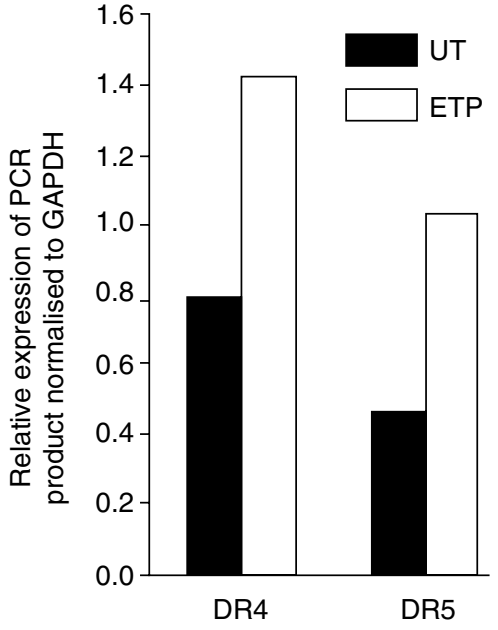

DcR1

DcR2

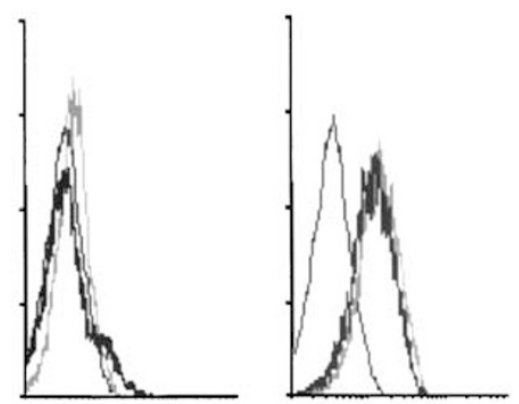

Figure 7 Effect of chemotherapeutic agents on the expression of DR4 and DR5. (A) Analysis of Apo2L/TRAIL receptor mRNA expression in the BTKI 43 osteosarcoma cells, assessed by semiquantitative RT-PCR analysis, as described in the Materials and Methods. Expression of the housekeeping gene, GAPDH, served to normalise for starting mRNA. Right panel shows the pattern of Apo2L/TRAlL receptor expression for late-passage untreated and ETPtreated BTK-I 43 cells. Left panel: Fluorimager-generated images of PCR products for DR4 and DR5 shown in the upper panel were quantitated using IMAGEQUANT software (Molecular Dynamics, Sunnyvale, CA, USA). (B) Flow cytometric data of cell surface expression of Apo2L/TRAIL receptors shows increased expression of DR4 and DR5 following treatment with ETP (heavy line) compared with untreated cells (grey line). The IB5 isotype-matched (IgGI) murine monoclonal antibody was used as a negative control (light line). 
Esposti, 1999; Keane et al, 1999; Zhang et al, 2000a,b), the overexpression of intracellular inhibitory proteins such as FLIP (Griffith et al, 1998), intracellular inhibitor of apoptosis molecules (IAPs) (Suliman et al, 2001) and the loss of caspase- 8 activity by gene methylation (Siegmund et al, 2001). Although the inherent expression of the decoy receptors for Apo2L/TRAIL was thought to be the main determinant of Apo2L/TRAIL resistance, it is, however, unlikely to be the sole reason given that we (Evdokiou et al, 2002), and others (Degli-Esposti, 1999; Lacour et al, 2001), have not been able to demonstrate a consistent correlation between Apo2L/TRAIL receptor expression and sensitivity to Apo2L/ TRAIL-induced apoptosis.

It is known that cellular responses to Apo2L/TRAIL depend on a complex interplay between the death and decoy receptors, and possibly OPG, as well as the participation of proapoptotic and prosurvival intracellular molecules such as FADD, FLIP, NFKB and Akt/PKB (Chaudhary et al, 1997; Nesterov et al, 2001; Ravi et al, 2001). It is possible that in a given tissue type, tumour or cell line, it is the balance of the numerous proapoptotic and prosurvival factors that determines the response to Apo2L/TRAIL, and that the perturbation of this balance by a single component may be enough to change the magnitude or the nature of the response.

Our data suggest that the gain in function or upregulation of the decoy receptors, in particular DcR2, may be important in the acquired loss of sensitivity to Apo2L/TRAIL in the osteosarcoma cell line BTK-143. DcR2 expression in BTK-143 cells progressively increased with passage in culture, and this increase correlated with a loss of sensitivity of these cells to Apo2L/TRAIL. Furthermore, blocking the function of DcR2 in the resistant cells resensitised them to Apo2L/TRAIL-induced apoptosis. In light of this result, it is possible that DcR2 is able to provide intracellular antiapoptotic signals, possibly through transcriptional regulation of other antiapoptotic genes, and further experiments will need to be performed to test this possibility.

The reasons for the loss of sensitivity that occurred with continued passaging in the present experiments are unclear, as these cells had presumably been extensively passaged prior to their acquisition for the study reported here. However, the results suggest that the culture conditions used for the present experiments induced DcR2 expression and thus selected for a more resistant phenotype. It is well established that some tumour types, as well as subpopulations of cells within a tumour type, are resistant to Apo2L/TRAIL-induced apoptosis (Bin et al, 2002). Also, it has been reported that melanoma cells are frequently resistant at the time of surgical excision, but regain sensitivity in cell culture (Nguyen et al, 2001). A similar effect has been demonstrated in platelets that have been stored for transfusion, where there is an early increase in the expression of DcR2, but this increase in expression is not enough to protect platelets from lesion, caused by apoptosis and caspase activation of these cells (Plenchette et al, 2001). It is therefore important to develop an understanding of the factors that lead to sensitivity or resistance of tumour cells to Apo2L/TRAIL.

We (Evdokiou et al, 2002), and others (Gliniak and Le, 1999; Desjosez et al, 2000; Gibson et al, 2000; Nagane et al, 2000; Yamanaka et al, 2000; Lacour et al, 2001; Mizutani et al, 2001),

\section{REFERENCES}

Ashkenazi A, Dixit VM (1998) Death receptors: signaling and modulation. Science 281: $1305-1308$

Ashkenazi A, Pai RC, Fong S, Leung S, Lawrence DA, Marsters SA, Blackie C, Chang L, McMurtrey AE, Hebert A, DeForge L, Koumenis IL, Lewis D, Harris L, Bussiere J, Koeppen H, Shahrokh Z, Schwall RH (1999) Safety and antitumor activity of recombinant soluble Apo2 ligand. J Clin Invest 104: $155-162$ have shown that Apo2L/TRAIL can be successfully combined with currently used chemotherapeutic treatments to sensitise already resistant cancer cells to Apo2L/TRAIL-induced apoptosis. In the present experiments, combining sublethal concentrations of the chemotherapeutic drugs DOX, CDDP and ETP with Apo2L/TRAIL reversed the loss of sensitivity in BTK-143 cells and restored the initial apoptotic effect. The resensitisation to the effects of Apo2L/ TRAIL by chemotherapy was associated with drug-induced upregulation of death receptors DR4 and DR5 at the level of mRNA and protein. This further supports the hypothesis that perturbation of the balance between the expression of death and decoy receptors is important in governing sensitivity to Apo2L/ TRAIL-induced apoptosis. Presumably, exposure to sublethal concentrations of chemotherapeutic agents such as those described here, altered the balance of these factors in favour of apoptosis by a process involving upregulation of death receptors. In contrast, we recently showed that normal human osteoblasts maintain viability in response to chemotherapeutic drugs and Apo2L/TRAIL combinations, by coregulating the expression of several antiapoptotic factors as the expression of death receptors is induced (Atkins et al, 2002). The molecular mechanisms by which chemotherapeutic drugs induce DR4 and DR5 expression are not yet understood and are under intense investigation by this laboratory. Many anticancer drugs are known to activate the tumour suppressor protein $\mathrm{p} 53$, which can in turn upregulate expression of death receptors DR4 and DR5 (Gibson et al, 2000). However, we and others have previously shown that chemotherapy can also induce expression of DR4 and/or DR5 in cancer cells that are null or mutant for p53 suggesting that p53-dependent and -independent mechanisms may be involved (Evdokiou et al, 2002). The BTK-143 osteosarcoma cell line used in this study expresses p53, but whether this protein is wild type or mutant has not been ascertained.

In summary, our results indicate that the acquisition of function or the upregulation of decoy receptors, in particular DcR2, is important in the loss of sensitivity to Apo2L/TRAIL-induced apoptosis. However, using low concentrations of currently used chemotherapeutic agents in combination with Apo2L/TRAIL, the acquired resistance of these cancer cells was reversed. This implies that future combination therapeutic regimens involving recombinant Apo2L/TRAIL and standard chemotherapeutic drugs for the treatment of osteosarcoma and other cancer types, may not only provide a more effective treatment, but would also require lower doses of drugs than those currently used. The use of such treatment regimens has exciting implications for reducing the frequency and the extent of the morbidity experienced by many cancer patients as a result of both their disease and of their treatment.

\section{ACKNOWLEDGEMENTS}

This work was supported by grants from the Cancer Council of South Australia, the Adelaide Bone and Joint Research Foundation, the Royal Adelaide Hospital, Adelaide University and the Australian Orthopaedic Association Research Foundation.
Atkins GJ, Bouralexis S, Evdokiou A, Hay S, Labrinidis A, Zannettino ACW, Haynes DR, Findlay DM (2002) Human osteoblasts are resistant to Apo2L/TRAIL-mediated apoptosis. Bone 31: 448-456

Bin L, Li X, Xu LG, Shu HB (2002) The short splice form of Casper/c-FLIP is a major cellular inhibitor of TRAIL-induced apoptosis. Febs Lett 510: 37-40 Bramwell VH (2000) Osteosarcomas and other cancers of bone. Curr Opin Oncol 12: $330-336$ 
Chaudhary PM, Eby M, Jasmin A, Bookwalter A, Murray J, Hood L (1997) Death receptor 5, a new member of the TNFR family, and DR4 induce FADD-dependent apoptosis and activate the NF-kappaB pathway. Immunity 7: $821-830$

Degli Esposti M (1999) To die or not to die-the quest of the TRAIL receptors. J Leukoc Biol 65: 535-542

Degli Esposti MA, Dougall WC, Smolak PJ, Waugh JY, Smith CA, Goodwin RG (1997a) The novel receptor TRAIL-R4 induces NF-kappaB and protects against TRAIL-mediated apoptosis, yet retains an incomplete death domain. Immunity 7: 813-820

Degli-Esposti MA, Smolak PJ, Walczak H, Waugh J, Huang CP, DuBose RF, Goodwin RG, Smith CA (1997b) Cloning and characterization of TRAILR3, a novel member of the emerging TRAIL receptor family. $J$ Exp Med 186: $1165-1170$

Dejosez M, Ramp U, Mahotka C, Krieg A, Walczak H, Gabbert HE, Gerharz CD (2000) Sensitivity to TRAIL/APO-2L-mediated apoptosis in human renal cell carcinomas and its enhancement by topotecan. Cell Death Differ 7: $1127-1136$

Emery JG, McDonnell P, Burke MB, Deen KC, Lyn S, Silverman C, Dul E, Appelbaum ER, Eichman C, DiPrinzio R, Dodds RA, James IE, Rosenberg M, Lee JC, Young PR (1998) Osteoprotegerin is a receptor for the cytotoxic ligand TRAIL. J Biol Chem 273: $14363-14367$

Evdokiou A, Bouralexis S, Atkins GJ, Chai F, Hay S, Clayer M, Findlay DM (2002) Chemotherapeutic agents sensitize osteogenic sarcoma cells, but not normal human bone cells, to Apo2L/TRAIL-induced apoptosis. Int J Cancer 99: 491 - 504

Gibson SB, Oyer R, Spalding AC, Anderson SM, Johnson GL (2000) Increased expression of death receptors 4 and 5 synergizes the apoptosis response to combined treatment with etoposide and TRAIL. Mol Cell Biol 20: $205-212$

Gliniak B, Le T (1999) Tumor necrosis factor-related apoptosis-inducing ligand's antitumor activity in vivo is enhanced by the chemotherapeutic agent CPT-11. Cancer Res 59: 6153-6158

Griffith TS, Chin WA, Jackson GC, Lynch DH, Kubin MZ (1998) Intracellular regulation of TRAIL-induced apoptosis in human melanoma cells. J Immunol 161: 2833-2840

Keane MM, Ettenberg SA, Nau MM, Russell EK, Lipkowitz S (1999) Chemotherapy augments TRAIL-induced apoptosis in breast cell lines. Cancer Res 59: 734-741

Lacour S, Hammann A, Wotawa A, Corcos L, Solary E, Dimanche-Boitrel MT (2001) Anticancer agents sensitize tumor cells to tumor necrosis factor-related apoptosis-inducing ligand-mediated caspase- 8 activation and apoptosis. Cancer Res 61: 1645-1651

Marsters SA, Sheridan JP, Pitti RM, Huang A, Skubatch M, Baldwin D, Yuan J, Gurney A, Goddard AD, Godowski P, Ashkenazi A (1997) A novel receptor for Apo2L/TRAIL contains a truncated death domain. Curr Biol 7: $1003-1006$

Medina V, Edmonds B, Young GP, James R, Appleton S, Zalewski PD (1997) Induction of caspase-3 protease activity and apoptosis by butyrate and trichostatin A (inhibitors of histone deacetylase): dependence on protein synthesis and synergy with a mitochondrial/cytochrome $c$ dependent pathway. Cancer Res 57: $3697-3707$

Mizutani Y, Nakao M, Ogawa O, Yoshida O, Bonavida B, Miki T (2001) Enhanced sensitivity of bladder cancer cells to tumor necrosis factor related apoptosis inducing ligand mediated apoptosis by cisplatin and carboplatin. J Urol 165: 263-270

Nagane M, Pan G, Weddle JJ, Dixit VM, Cavenee WK, Huang HJ (2000) Increased death receptor 5 expression by chemotherapeutic agents in human gliomas causes synergistic cytotoxicity with tumor necrosis factor-related apoptosis-inducing ligand in vitro and in vivo. Cancer Res 60: $847-853$

Nagata S (1997) Apoptosis by death factor. Cell 88: $355-365$

Nesterov A, Lu X, Johnson M, Miller GJ, Ivashchenko Y, Kraft AS (2001) Elevated AKT activity protects the prostate cancer cell line LNCaP from TRAIL-induced apoptosis. J Biol Chem 276: $10767-10774$
Newton K, Kurts C, Harris AW, Strasser A (2001) Effects of a dominant interfering mutant of FADD on signal transduction in activated $\mathrm{T}$ cells. Curr Biol 11: 273-276

Nguyen T, Zhang XD, Hersey P (2001) Relative resistance of fresh isolates of melanoma to tumor necrosis factor-related apoptosis-inducing ligand (TRAIL)-induced apoptosis. Clin Cancer Res 7: 966s-973s

Pan G, O’Rourke K, Chinnaiyan AM, Gentz R, Ebner R, Ni J, Dixit VM (1997a) The receptor for the cytotoxic ligand TRAIL. Science 276: $111-113$

Pan G, Ni J, Wei YF, Yu G, Gentz R, Dixit VM (1997b) An antagonist decoy receptor and a death domain-containing receptor for TRAIL. Science 277: $815-818$

Pan G, Ni J, Yu G, Wei YF, Dixit VM (1998) TRUNDD, a new member of the TRAIL receptor family that antagonizes TRAIL signalling. FEBS Lett 424 $41-45$

Plenchette S, Moutet M, Benguella M, N'Gondura JP, Guigner F, Coffe C, Corcos L, Bettaieb A, Solary E (2001) Early increase in DcR2 expression and late activation of caspases in the platelet storage lesion. Leukemia 15: $1572-1581$

Ravi R, Bedi GC, Engstrom LW, Zeng Q, Mookerjee B, Gelinas C, Fuchs EJ, Bedi A (2001) Regulation of death receptor expression and TRAIL/ Apo2L-induced apoptosis by NF-kappaB. Nat Cell Biol 3: 409-416

Roy S, Nicholson DW (2000) Cross-talk in cell death signaling. J Exp Med 192: F21-F25

Seki K, Yoshikawa H, Shiiki K, Hamada Y, Akamatsu N, Tasaka K (2000) Cisplatin (CDDP) specifically induces apoptosis via sequential activation of caspase-8, -3 and -6 in osteosarcoma. Cancer Chemother Pharmacol 45: $199-206$

Sheridan JP, Marsters SA, Pitti RM, Gurney A, Skubatch M, Baldwin D, Ramakrishnan L, Gray CL, Baker K, Wood WI, Goddard AD, Godowski P, Ashkenazi A (1997) Control of TRAIL-induced apoptosis by a family of signaling and decoy receptors. Science 277: 818-821

Siegmund D, Mauri D, Peters N, Juo P, Thome M, Reichwein M, Blenis J, Scheurich P, Tschopp J, Wajant H (2001) Fas-associated death domain protein (FADD) and caspase- 8 mediate up-regulation of c-Fos by Fas ligand and tumor necrosis factor-related apoptosis-inducing ligand (TRAIL) via a FLICE inhibitory protein (FLIP)-regulated pathway. J Bio Chem 276: 32585 - 32590

Suliman A, Lam A, Datta R, Srivastava RK (2001) Intracellular mechanisms of TRAIL: apoptosis through mitochondrial-dependent and -independent pathways. Oncogene 20: $2122-2133$

Truneh A, Sharma S, Silverman C, Khandekar S, Reddy MP, Deen KC, McLaughlin MM, Srinivasula SM, Livi GP, Marshall LA, Alnemri ES, Williams WV, Doyle ML (2000) Temperature sensitive differential affinity of TRAIL for its receptors: DR5 is the highest affinity receptor. J Biol Chem 275: 23319-23325

Walczak H, Degli Esposti MA, Johnson RS, Smolak PJ, Waugh, JY, Boiani N, Timour MS, Gerhart MJ, Schooley KA, Smith CA, Goodwin RG, Rauch CT (1997) TRAIL-R2: a novel apoptosis-mediating receptor for TRAIL. Embo J 16: 5386-5397

Walczak H, Miller RE, Ariail K, Gliniak B, Griffith TS, Kubin M, Chin W, Jones J, Woodward A, Le T, Smith C, Smolak P, Goodwin RG, Rauch CT, Schuh JC, Lynch DH (1999) Tumoricidal activity of tumor necrosis factor-related apoptosis-inducing ligand in vivo [see comments]. Nat Med 5: $157-163$

Yamanaka T, Shiraki K, Sugimoto K, Ito T, Fujikawa K, Ito M, Takase K, Moriyama M, Nakano T, Suzuki A (2000) Chemotherapeutic agents augment TRAIL-induced apoptosis in human hepatocellular carcinoma cell lines. Hepatology 32: $482-490$

Zhang XD, Franco AV, Nguyen T, Gray CP, Hersey P (2000a) Differential localization and regulation of death and decoy receptors for TNF-related apoptosis-inducing ligand (TRAIL) in human melanoma cells. J Immunol 164: $3961-3970$

Zhang XD, Nguyen T, Thomas WD, Sanders JE, Hersey P (2000b) Mechanisms of resistance of normal cells to TRAIL induced apoptosis vary between different cell types. FEBS Lett 482: 193-199 